\title{
PENGEMBANGAN MODUL IPA TERPADU BERBASIS KETERAMPILAN PROSES SAINS PADA MATERI SISTEM PERNAPASAN UNTUK PESERTA DIDIK SMP KELAS VIII
}

\begin{abstract}
A Nuur Taufik Rahmat *) SMPN 4 Tapalang Barat
\end{abstract}

Ramlawati Universitas Negeri Makassar

Muhammad Aqil Rusli Universitas Negeri Makassar
*) Correspondence Author: nuurtaufikrahmat@gmail.com
Abstrak: Penelitian ini bertujuan untuk menghasilkan modul berbasis keterampilan proses sains yang valid dan efektif. Subjek penelitian ini adalah peserta didik kelas VIII SMPN 4 Bulukumba. Penelitian ini menggunakan model 4D Thiagarajan (Define, Design, Develop, Disseminate). Modul IPA yang dikembangkan menggunakan keterpaduan model Webbed. Modul yang dikembangkan berbasis keterampilan proses sains, yang meliputi mengamati, merumuskan masalah, menyusun hipotesis, merancang percobaan, mengkomunikasikan dan menyimpulkan. Hasil penelitian menunjukkan bahwa terdapat peningkatan keterampilan proses sains peserta didik. Teknik pengumpulan data dengan instrumen lembar validasi ahli dan tes untuk menilai keefektifan. Hasil penelitian menunjukkan bahwa pengujian pada tim ahli/pakar menunjukkan bahwa rata-rata skor perangkat tergolong valid. Hal ini berarti modul yang dikembangkan sudah layak untuk digunakan. Selanjutnya persentase hasil penilaian keefektifan modul yang diukur dengan tes keterampilan proses sains menunjukkan skor tes ratarata berada pada ketegori tinggi. Berdasarkkan hasil penelitian maka dapat disimpulkan bahwa modul IPA terpadu berbasis keterampilan proses sains yang dikembangkan memenuhi kriteria kevalidan dan efektif.

Kata Kunci: Modul IPA Terpadu, Keterampilan Proses Sains, Sistem Pernapasan

Abstract: This study aims to produce a valid and effective module based on science process skills. The subject of this research is the students of 8th grade of Junior High School Bulukumba. This study uses the Thiagarajan 4D model (Define, Design, Develop, Disseminate). The science module developed uses the model Webbed. The module is developed based on science process skills, which includes observing, formulating problems, formulating hypotheses, designing experiments, communicating and concluding. The results of the study indicate that there is an increase in science process skills of students. Data collection techniques with instruments of expert validation sheets and tests to assess effectiveness. The results showed that testing on a team of experts / experts showed that the average device score was valid. This means that the modules developed are suitable for use. Furthermore, the percentage of the results of the evaluation of the effectiveness of the module as measured by the science process skills test shows that the average test score is in the high category. Based on the results of the study, it can be concluded that the developed integrated science module based on science process skills meets the criteria for validity and effectiveness.

Keyword: Integrated Science Module, Science Process Skills, Respiratory System, Learning Outcomes. 


\section{PENDAHULUAN}

Indonesia dalam usia 72 tahun setelah kemerdekaan terus melakukan perubahan khususnya dalam bidang pendidikan sesuai dengan Undang-Undang Nomor 20 Tahun 2003 tentang Sistem Pendidikan Nasional, Pasal 1 angka 1 menyatakan bahwa pendidikan adalah usaha sadar dan terencana untuk mewujudkan suasana belajar dan proses pembelajaran agar peserta didik secara aktif mengembangkan potensi dirinya untuk memiliki kekuatan spiritual keagamaan, pengendalian diri, kepribadian, kecerdasan, akhlak mulia, serta keterampilan yang diperlukan dirinya, masyarakat, bangsa dan negara.

Melihat peranan pendidikan yang sangat penting tersebut, maka pendidikan di Indonesia terus berkembang untuk membentuk sebuah sistem yang lebih baik. Dalam sejarah perjalanan kemerdekaan pada tahun 1945, kurikulum pendidikan nasional telah mengalami Sembilan kali perubahan dengan perubahan terbaru pada Kurikulum Tingkat Satuan Pendidikan (KTSP) tahun 2006 menjadi Kurikulum 2013. Perubahan tersebut merupakan konsekuensi logis dari terjadinya sistem politik, sosial budaya, ekonomi dan iptek dalam berbangsa dan bernegara. Sebab, kurikulum sebagai seperangkat rencana pendidikan perlu dikembangkan secara dinamis sesuai dengan tuntutan dan perubahan yang terjadi di masyarakat.

IImu Pengetahuan Alam (IPA) merupakan salah satu muatan kurikulum yang wajib dilaksanakan dalam kegiatan pembelajaran pada jenjang pendidikan dasar dan menengah. Yuliati, L (2013:53) mengemukakan pemberlakuan Kurikulum Tingkat Satuan Pendidikan (KTSP) pada tahun 2006 yang mengacu pada Standar Isi berdampak pada pembelajaran IPA di SMP/MTs yaitu materi pelajaran IPA yang mencakup bidang kajian fisika, biologi dan kimia harus diajarkan secara terpadu dan berlanjut pada kurikulum 2013.

Penerapan pembelajaran IPA secara terpadu saat ini masih mengalami beberapa kendala. Kendala tersebut mencakup pelaksanaan dan ketersediaan bahan ajar. Melalui observasi yang dilakukan di sekolah SMP Negeri 4 Bulukumba, diperoleh informasi bahwa pendidik IPA di sekolah tersebut masih belum menerapkan keterpaduan. Pada pembelajaran IPA pendidik mengajarkan materi secara terpisah satu sama lain, kemudian sumber belajar yang berupa buku paket yang berasal dari penerbit cenderung mengacu pada salah satu bidang kajian IPA, misalnya fisika, kimia, atau biologi sehingga penyajian materi IPA dilakukan terpisah antara kajian satu dengan kajian lainnya.

Pengmbangan bahan ajar terpadu berupa modul IPA telah dilakukan oleh Musari (2016:26) pada tema Makanan Sehat dan Tubuhku di MTs YAPPI Mulusan menujukkan bahwa modul IPA dapat meningkatkan hasil belajar kognitif. Namun modul IPA terebut hanya berisi kumpulan pengetahuan berupa produk saja, seperti konsep dan teori yang bertujuan meningkatkan hasil belajar kognitif peserta didik, sedangkan pengetahuan peserta didik berupa proses penyelidikan atau penemuan, tidak terdapat di dalam modul IPA Terpadu tersebut

Menurut Permendiknas Nomor 22 tahun 2006, proses pembelajaran IPA menekankan pada pemberian pengalaman langsung untuk mengembangkan kompetensi agar menjelajahi dan memahami alam sekitar secara ilmiah. Sains atau IPA berhubungan dengan cara mencari tahu tentang alam secara terencana dan sistematis. Sains atau IPA bukanlah sekedar kumpulan pengetahuan yang berupa fakta-fakta, konsep-konsep, atau prinsip-prinsip tetapi juga merupakan proses mencari dan menemukan. Proses pembelajaran sains sebaiknya menekankan pada pemberian pengalaman langsung kepada peserta didik melalui langkah-langkah kerja ilmiah sebagai mana dilakukan oleh ilmuan. Proses kerja seperti ilmuan itulah dikenal sebagai metode ilmiah. Dalam praktek pembelajaran, maka kegiatan belajar melalui proses kerja ilmiaih akan melibatkan keterampilan yang disebut dengan keterampilan proses sains (Jufri, 2017: 149).

Peneliti dalam hal ini akan mengembangkan modul berbasis keterampilan proses sains, di mana pembelajaran yang didapatkan oleh peserta didik tidak hanya terfokus pada penguasaan konsep dan teori, namun juga keterampilan yang didapatkan melalui proses kerja ilmiah, hal ini 
akan mudahkan peserta didik dalam memahami konsep-konsep yang rumit dan abstrak jika disertai dengan contoh-contoh konkrit, dan ini merupakan salah satu alasan yang melandasi perlunya diterapkan keterampilan proses sains. Modul pada dasarnya merupakan bahan ajar yang disusun secara sistematis dengan menggunakan bahasa yang mudah dipahami oleh peserta didik sesui dengan tingkat pengetahuan agar mereka dapat belajar sendiri (mandiri) dengan bantuan atau bimbingan yang minimal dari pendidik (Prastowo, 2014: 209).

Sistem pernapasan merupakan materi pokok yang akan dibuatkan bahan ajar berupa modul berbasis keterampilan proses sains. Materi ini pada pelaksanaan dilapangan, pembelajaran condong hanya mengajarkan pada aspek bidang kajian biologi dan tidak memasukkan bidang kajian fisika dan kimia, sementara jika ditinjau pada kajian materi tersebut banyak terdapat keterkaitan antara bidang kajian kimia, fisika, dan biologi. Terlebih dalam materi ini sangat berkaitan dengan kehidupan sehari-hari peserta didik, karena merupakan aktifitas tubuh sehingga pembelajaran menjadi lebih bermakna. Materi ini juga akan dibuatkan tema rokok diamana dalam kalangan remaja rokok merupakan barang yang sering dijumpai dan disalah gunakan oleh remaja, maka dengan tema ini diharapkan peserta didik mampu mngetahui bahaya dan akibat yang ditimbulkan rokok, disamping itu dimodul ini peserta didik dituntut mampu mengembangkan indikator keterampilan proses sains berupa observasi, prediksi, merumuskan hipotesis, melaksanakan percobaan, menarik kesimpulan dan mengkomunikasikan. Seperangkat keterampilan yang akan dijalankan oleh peserta didik dalam keterampilan proes sains merupakan keterampilan yang diperoleh untuk menerapkan metodeh ilmiah guna memahami, menemukan dan mengembangkan ilmu pengetahuan.

Berdasarkan latar belakang masalah di atas dan uraian yang telah dikemukakan peneliti, mengenai bahan ajar maka peneliti akan mengembangkan "Modul IPA Terpadu Berbasis Keterampilan Proses Sains Pada Materi Sistem Pernapasan".

\section{METODE}

Penelitian ini merupakan penelitian Educational Reseach and Development (R\&D) yaitu metode penelitian yang digunakan untuk menghasilkan suatu produk pendidikan, dan menguji keefektifan produk tersebut dalam bidang pendidikan. Penelitian yang dilakukan merupakan pengembangan bahan ajar berupa modul IPA terpadu berbasis keterampilan proses sains pada materi sistem pernapasan. Model pengembangan perangkat pembelajaran yang digunakan adalah model Thiagarajan. Model Thiagarajan terdiri dari 4 tahap yang dikenal dengan model 4D (four D model). Keempat tahap tersebut adalah tahap pendefinisian (define), tahap perencanaan (design), tahap pengembangan (development) dan tahap penyebaran (disseminate) yang dimana pada penelitian ini hanay sampai pada tahap pengembangan.

Model ketepaduan yang digunakan pada pengembangan modul berbasis keterampilan proses sains ini adalah model wabbed. Instrumen pengumpulan data pada penelitian ini adalah dengan metode tes.

\section{HASIL DAN PEMBAHASAN}

\section{Hasil}

Tahapan pertama yaitu define tahap ini merupakan tahap untuk menetapkan dan mendefinisikan kebutuhan-kebutuhan pembelajaran dengan menganalisis tujuan dalam pengembangan pembelajaran, Berdasarkan hasil analisis awal akhir diperoleh informasi bahwa SMP Negeri 4 Bulukumba menggunakan Kurikulum 2013 sejak tahun 2016. Implementasi pembelajaran dengan menggunakan Kurikulum 2013 di sekolah tersebut masih terdapat kendala yang ditemukan khususnya pada proses pembelajaran, di mana kegiatan pembelajaran yang 
terdapat didalam RPP berpusat pada peserta didik (student centerd) namun, berdasarkan observasi yang dilakukan justru proses pembelajaran berfokus pada pendidik (teacher centered). Dampak yang terjadi adalah peserta didik belum mampu bekerja secara mandiri dan aktif.

Materi IPA yang akan dikembangkan adalah materi sistem pernapasan dengan KD 3.9 Menganalisis sistem pernapasan pada manusia dan memahami gangguan pada sistem pernapasan serta upaya menjaga kesehatan sistem pernapasan, kemudian KD 4.9 Menyajikan karya tentang upaya menjaga kesehatan. Bahan ajar yang digunakan berupa buku paket yang dibagikan oleh kementrian pendidikan dan modul yang dibuat sendiri oleh pendidik. Pada modul yang digunkana hanya berisi uraian materi yang disertai beberapa gambar pendukung tanpa dilengkapi dengan aktivitas pembelajaran dan evaluasi. Sehingga modul tersebut terkesan monoton pada uraian materi saja tanpa adanya aktifitas pembelajaran yang mampu mengasah kegiatan ilmiah peserta didik sesuai dengan standar proses pembelajaran di Kurikulum 2013. Masalah lain yang ditemukan adalah pembelajaran untuk materi sistem pernapasan masih diajarkan dominan pada aspek biologi saja. Hal ini tidak sesuai dengan tuntutan Kurikulum 2013 yang menyatakan bahwa pembelajaran IPA harus diajarkan secara terpadu yang memuat tiga aspek yang tidak dapat dipisahkan yakni Fisika, Biologi, dan Kimia.

Analisis peserta didik dilakukan untuk mengetahui karakteristik peserta didik. Dalam proses pembelajaran pendidik harus menyesuaikan dengan karakteristik belajar peserta didik itu sendiri sehingga tujuan yang diinginkan dalam proses pembelajaran dapat tercapai. Kurikulum 2013 dalam silabus yang dikeluarkan oleh kementrian pendidikan dan kebudayaan menyebutkan proses pembelajaran IPA menggunakan metode ilmiah mengamati, merumuskan masalah, merumuskan hipotesis, melakukan percobaan, mengkomunikasikan, dan menyimpulkan. Peserta didik dalam proses pembelajaran sebelumnya pernah melakukan beberapa metode ilmiah di atas melalui kegiatan dalam modul pendidik, namun peserta didik kurang paham dalam melakukan kegiatan ilmiah tersebut, hal ini didapatakan melalui pemberian pertanyaan kepeserta didik mengenai cara penggunaan metode ilmiah, namun peserta didik tidak dapat menjelaskan proses tersebut dengan tepat, sehingga dalam kegiatan menggunakan metode ilmiah tersebut tidak sesuai dengan harapan yang diinginkan.

Analisis konsep dilakukan untuk mengidentifikasi, merinci dan menyusun secara sistematis konsep-konsep utama yang akan dipelajari peserta didik berdasarkan Kurikulum 2013. Materi ajar yang dipilih pada penelitian ini adalah sistem pernapasan dengan tiga tema utama yaitu, pernapasan, mekanisme pernapasan, dan rokok

Tahapan kedua yaitu design yang bertujuan untuk merancang perangkat pembelajaran. Pemilihan media dilakukan untuk mengidentifikasi media pembelajaran yang sesuai dengan karakteristik materi. Proses yang dilakukan pada pemilihan media yaitu menyesuaikan analisis tugas, analisis materi, karakteristik peserta didik dan fasilitas yang tersedia di sekolah. Adapun media yang digunakan adalah media audio visual berupa penampilan video pembelajaran, karena dalam materi ini membahas mengenai organ-organ dan mekanisme yang terjadi di dalam tubuh sehingga meminimalisir terjadinya kesalahan konsep peserta dididk, kemudian dalam video yang diperlihatkan juga terdapat stimulus untuk merangsang peserta didik dalam berpikir.

Pemilihan format disesuaikan dengan format yang diperlukan dalam modul. Sementara langkah pengembangan modul meliputi penulisan, pengadaptasian, pengeditan penelaahan modul yang dirancang. Langkah-langkah tersebut dilakukan dengan cara mengumpulkan bahan penulisan naskah yang terkait dengan materi yaitu berupa konsep, desain, dan gambar ilustrasi. Rancangan modul yang dibuat terlebih dahulu dikonsultasikan dengan pembimbing mengenai materi dan kegiatan-kegiatan yang akan dilakukan oleh peserta dididk, masukan yang diberikan akan menjadi bahan perbaikan dalam penyempurnaan modul yang dibuat.

Pertemuan pertama menampilakn video organ-organ pernapasan serta senyawa yang dihirup dan dikeluarkan tujuannya, untuk memperlihatkan organ-organ pernapasan yang ada didalam tubuh serta proses masuk dan keluarnya udara pernapasan. Pertemuan pertama ini 
ditunjang dengan kegiatan percobaan untuk mengetahui senyawa yang terlibat dalam proses pernapasan. Pertemuan kedua menampilkan video mekanisme pernapasan dan kapasitas paruparu tujuannya, untuk memperlihatkan mekanisme yang terjadi didalam tubuh ketika menghirup dan mengeluarkan udara. Pertemuan kedua ini ditunjang dengan kegiatan percobaan menghitung kapasitas paru-paru. Pertemuan ketiga menampilkan video bahaya rokok terhadap kesehatan yang tujuannya, untuk mengenalkan dampak yang ditimbulkan dari aktivitas merokok bagi kesehatan tubuh. Pertemuan ketiga ini ditunjang dengan kegiatn percobaan uji bahaya asap rokok.

Analisis tugas dilakukan untuk mengidentifikasikan keterampilan-keterampilan utama yang dilakukan peserta didik selama pembelajaran berdasarkan analisis konsep. Hasil analisis tugas ini bertujuan untuk membantu peserta didik untuk meningkatkan hasil belajar peserta didik dengan basisi keterampilan proses sains.

Pada pengerjaan modul, peserta didik dititik beratkan dalam pengerjaan secara individu dengan begitu peserta didik akan berperan aktif dan tertarik sehingga motivasi belajarnya akan meningkat, begitu pula dengan hasil belajarnya. Dalam pengerjaan tugas juga terdapat beberapa kegiatan yang harus dikerjakan secara berkelompok, tugas ini didesain dengan cara peserta didik berdiskusi, hasil dari diskusi akan memberi jawaban masing-masing individu peserta didik sesuai dengan sudut pandangnya.

Tahapan ketiga adalah develope, pada tahap ini dilakukan tahapan validasi, uji coba terbatas dan uji coba kelas. Tahapan pengembangan ini bertujuan untuk menghasilkan sebuah produk modul IPA berbasis keterampilan proses sains yang sudah siap nantinya untuk disebarkan atau diujicobakan lebih luas lagi setelah dilakukan revisi sesuai dengan validasi dan revisi pada tahap uji coba. Produk berupa draf modul I divalidasi oleh 2 orang dosen ahli. Secara lengkap tersaji pada tabel 1. Setelah draf modul I divalidasi dan direvisi sesuai dengan saran para validator maka draf modul siap diujicobakan pada kelompok kecil. Pada penelitian ini, kelompok kecil yang digunakan sebanyak 12 orang.

\section{Tabel 1. Hasil Validasi Modul}

\begin{tabular}{cccc}
\hline No. & Aspek Penilaian & Content Validity & Keterangan \\
\hline 1. & Format & 1 & Valid \\
2. & Bahasa & 1 & Valid \\
3. & Isi & 1 & Valid \\
4. & Manfaat modul & 1 & Valid \\
\hline & Rata-rata total & $\mathbf{1}$ & Valid \\
\hline
\end{tabular}

Hasil validasi terhadap modul yang dikembangkan mempunyai nilai rata-rata 1 yang tergolong dalam kategori valid. Dinyatakan kategori valid apabila nilai hasil validasi berada pada nilai $\geq 0,75$. Modul berbasis keterampilan proses sains yang dinilai keefektifannya diukur melalu pemeberian pre test dan post test. Berikut perolehan rekapitulasi skor yang diperoleh.

Tabel 2. Rekapitulasi Skor Pre test dan Post test Keterampilan Proses Sains

\begin{tabular}{cccc}
\hline $\begin{array}{c}\text { Rentang } \\
\text { Skor }\end{array}$ & Frekuensi Peserta Didik (Pretest) & Frekuensi Peserta Didik (Posttest) & Kategori \\
\hline $19-20$ & 0 & 5 & Sangat baik \\
$17-18$ & 0 & 5 & Baik \\
$15-16$ & 0 & 2 & Cukup \\
$13-14$ & 0 & 0 & Kurang \\
$<12$ & 12 & 0 & Sangat kurang \\
\hline
\end{tabular}


Analisis indikator tes keterampilan proses sains dengan perolehan skor perindikator pada saat pre test dan post test dengan menggunakan soal yang mewakili setiap indikator keterampilan proses sains meliputi mengamati pada indikator 1 , merumuskan masalah pada indikator 2, merumuskan hipotesis pada indikator3, melakukan percobaan pada indikator 4, mengkomunikasikan pada indikator 5, dan menyimpulkan pada indikator 6. Perolehan skor peserta didik dapat dilihat pada tabel dibawah ini.

Tabel 3. Skor Perindikator

\begin{tabular}{|c|c|c|}
\hline \multirow{2}{*}{ Jumlah Perolehan Skor } & \multicolumn{2}{|c|}{ Indikator 1} \\
\hline & Frekuensi Peserta Didik (Pretest) & Frekuensi Peserta Didik (Posttest) \\
\hline 3 & 1 & 10 \\
\hline 2 & 0 & 2 \\
\hline 1 & 6 & 0 \\
\hline 0 & 5 & 0 \\
\hline \multirow{2}{*}{ Jumlah Perolehan Skor } & \multicolumn{2}{|c|}{ Indikator 2} \\
\hline & Frekuensi Peserta Didik (Pretest) & Frekuensi Peserta Didik (Posttest) \\
\hline 4 & 0 & 7 \\
\hline 3 & 2 & 4 \\
\hline 2 & 5 & 0 \\
\hline 1 & 3 & 1 \\
\hline 0 & 2 & 0 \\
\hline \multirow{2}{*}{ Jumlah Perolehan Skor } & \multicolumn{2}{|c|}{ Indikator 3} \\
\hline & Frekuensi Peserta Didik (Pretest) & Frekuensi Peserta Didik (Posttest) \\
\hline 3 & 0 & 9 \\
\hline 2 & 2 & 3 \\
\hline 1 & 4 & 0 \\
\hline 0 & 6 & 0 \\
\hline \multirow{2}{*}{ Jumlah Perolehan Skor } & \multicolumn{2}{|c|}{ Indikator 4} \\
\hline & Frekuensi Peserta Didik (Pretest) & Frekuensi Peserta Didik (Posttest) \\
\hline 3 & 0 & 9 \\
\hline 2 & 2 & 3 \\
\hline 1 & 7 & 0 \\
\hline 0 & 3 & 0 \\
\hline \multirow{2}{*}{ Jumlah Perolehan Skor } & \multicolumn{2}{|c|}{ Indikator 5} \\
\hline & Frekuensi Peserta Didik (Pretest) & Frekuensi Peserta Didik (Posttest) \\
\hline 3 & 1 & 8 \\
\hline 2 & 1 & 3 \\
\hline 1 & 6 & 1 \\
\hline 0 & 4 & 1 \\
\hline \multirow{2}{*}{ Jumlah Perolehan Skor } & \multicolumn{2}{|c|}{ Indikator 6} \\
\hline & Frekuensi Peserta Didik (Pretest) & Frekuensi Peserta Didik (Posttest) \\
\hline 4 & 0 & 9 \\
\hline 3 & 0 & 1 \\
\hline 2 & 4 & 1 \\
\hline 1 & 5 & 0 \\
\hline 0 & 3 & 1 \\
\hline
\end{tabular}

\section{Pembahasan}

Berdasarkan hasil analisis yang telah dilakukan, menunjukkan tes keterampilan proses sains diberikan dengan tujuan untuk mengetahui pemahaman proses sains dan sikap ilmiah peserta 
didik. Tes ini dirancang sebanyak 20 butir soal pilihan ganda yang dimana setiap butir soal mengandung indikator keterampilan proses sains dasar. Keterampilan proses sains yang digunakan yakni mengobservasi, merumuskan masalah, menyusun hipotesis, merancang percobaan, mengkomunikasikan, dan menarik kesimpulan. Keenam indikator yang dipilih ini berdasarkan kemampuan peserta didik sesuai dengan jenjang pendidikan yang sedang mereka jalani sesuai standar proses Permendikbud No.22 tahun 2016. Tes ini diberikan kepada peserta didik pada awal sebelum melakukan uji coba (Pretest) dan akhir setelah melakukan uji coba (Posttest).

Pencapaian keterampilan proses sains dari skor rata-rata perolehan tes menunjukan bahwa rata-rata peserta didik yang menjadi subjek penelitian pengetahuan awalnya tentang keterampilan proses sains dilihat dari Pretest berada pada kategori sangat kurang dimana 12 peserta didik mendapatkan skor dibawah 12. Sedangkan untuk skor posttest berdasarkan Tabel. 2 sudah dapat dikatakan bahwa seluruh peserta didik mengalami peningkatan keterampilan proses sains. Hal ini ditandai dengan 5 peserta didik berada pada kategoti sangat baik, 5 peerta didik berada pada kategori baik, dan 2 peserta didik berada pada kategori cukup yang menjadi batas minimal skor perolehan yang dicapai. Hal ini sesuai dengan hasil penelitian Octavia (2015) bahwa Pengembangan modul IPA berbasis KPS ini dinilai efektif karena selain hasil belajar peserta didik yang meningkat, keterampilan proses sains dari peserta didik itu sendiri mengalami peningkatan. Jadi, dapat disimpulkan berdasarkan hasil di atas bahwa modul IPA terpadu berbasis keterampilan proses sains yang dikembangkan efektif meningkatkan keterampilan proses sains peserta didik.

\section{KESIMPULAN}

Berdasarkan hasil penelitian yang telah dilakukan pada peserta didik kelas VIII.B SMPN 4 Bulukumba dapat ditarik kesimpulan bahwa modul yang dikembangkan efektif dalam meningkatkan keterampilan proses sains peserta didik pada materi sistem pernapasan.

\section{DAFTAR PUSTAKA}

Jufri, W. (2017). Belajar Dan Pembelajaran Sains. Bandung: Pustaka Raka Cipta.

Muzari, I., Ashadi., \& Bakoro A. P. (2016). Pengembangan Modul IPA Terpadu Berbasisi Sets Pada Tema Makanan Sehat dan Tubuhku Untuk Meningkatkan Hasil Belajar. Jurnal Inkuiri, Vol. 5, No. 1.

Oktavia, R. (2015). Pengembangan Modul Pembelajaran IPA SMP pada Materi Tekanan Berbasis Keterampilan Proses Sains. Jurnal Pendidikan Fisika, Vol. 3, No. 1.

Kementrian Pendidikan \& Kebudayaan. (2017). Panduan Penilaian Oleh Pendidik Satuan Pendidikan Sekolah Menengah Pertama. Jakarta: Direktorat Pembinaan SMP.

Prastowo, A. (2014). Pengembangan Bahan Ajar Tematik. Jakarta: Prenadamedia Group.

Thiagarajan, S., Semmel D.S dan Semmel M.I. (1974). Instructional Development for Training Teachers of Expectacional Children. Indiana: University Bloomington.

Yuliati,L. (2013). Efektifitas Bahan Ajar IPA Terpadu Terhadap Kemampuan Berpikir Tingkat Tinggi Siswa SMP. Jurnal Pendidikan Fisika Indonesia, Vol. 13, No. 2. 


\begin{abstract}
A Nuur Taufik Rahmat
Guru bidang studi IPA di SMPN 4 Tapalang Barat, aktif melakukan penelitian pada bidang Pendidikan, dapat dihubungi melalui pos-el: nuurtaufikrahmat@gmail.com.

\section{Ramlawati}

Dosen Program Studi Pendidikan IPA FMIPA UNM, aktif melakukan penelitian pada bidang Pendidikan IPA.

\section{Muhammad Aqil Rusli}

Dosen Program Studi Pendidikan IPA FMIPA UNM, aktif melakukan penelitian pada bidang Pendidikan IPA.
\end{abstract}

